\title{
Regulation of proteinases during mouse peri-implantation development: urokinase-type plasminogen activator expression and cross talk with matrix metalloproteinase 9
}

\author{
M G Martínez-Hernández ${ }^{1,2}$, L A Baiza-Gutman ${ }^{1,2}$, A Castillo-Trápala² and D Randall Armant ${ }^{1,3}$ \\ ${ }^{1}$ Departments of Obstetrics and Gynecology and Anatomy and Cell Biology, C. S. Mott Center for Human Growth and \\ Development, Wayne State University School of Medicine, 275 East Hancock Avenue, Detroit, Michigan 48201, \\ USA, ${ }^{2}$ Laboratorio de Biología del Desarrollo, UMF, Universidad Nacional Autónoma de México, FES-Iztacala, \\ Iztacala, Tlalnepantla, Estado de México 54090, Mexico and ${ }^{3}$ Program in Reproductive and Adult Endocrinology, \\ NICHD, NIH, DHHS, Bethesda, Maryland 20892, USA
}

Correspondence should be addressed to D R Armant at Departments of Obstetrics and Gynecology and Anatomy and Cell Biology, C. S. Mott Center for Human Growth and Development, Wayne State University School of Medicine; Email: d.armant@wayne.edu

\begin{abstract}
Trophoblast cells express urokinase-type plasminogen activator (PLAU) and may depend on its activity for endometrial invasion and tissue remodeling during peri-implantation development. However, the developmental regulation, tissue distribution, and function of PLAU are not completely understood. In this study, the expression of PLAU and its regulation by extracellular matrix proteins was examined by RT-PCR, immunocytochemistry, and plasminogen-casein zymography in cultured mouse embryos. There was a progressive increase in Plau mRNA expression in blastocysts cultured on gestation days 4-8. Tissue-type plasminogen activator (55 kDa) and PLAU (a triplet of 40,37, and $31 \mathrm{kDa}$ ) were present in conditioned medium and embryo lysates, and were adsorbed to the culture plate surface. The temporal expression pattern of PLAU, according to semi-quantitative gel zymography, was similar in non-adhering embryos and embryos cultured on fibronectin, laminin, or type IV collagen, although type IV collagen and laminin upregulated Plau mRNA expression. Immunofluorescence revealed PLAU on the surface of the mural trophectoderm and in non-spreading giant trophoblast cells. Exogenous human plasminogen was transformed to plasmin by cultured embryos and activated endogenous matrix metalloproteinase 9 (MMP9). Indeed, the developmental expression profile of MMP9 was similar to that of PLAU. Our data suggest that the intrinsic developmental program predominantly regulates PLAU expression during implantation, and that PLAU could be responsible for activation of MMP9, leading to localized matrix proteolysis as trophoblast invasion commences.

Reproduction (2011) 141 227-239
\end{abstract}

\section{Introduction}

Plasminogen activators (PAs) have been implicated in the initiation of proteolytic cascades that mediate invasive processes. PAs are serine proteases that convert plasminogen to plasmin, the active form of a broadspecificity protease that can control extracellular matrix (ECM) turnover, either directly or indirectly, by activating some members of the matrix metalloproteinase (MMP) family (Lijnen 2002, Castellino \& Ploplis 2005, Rijken \& Lijnen 2009).

ECM adhesion and proteolysis play important roles during embryo implantation. The specialized interaction between embryonic and maternal tissues is unique to mammalian development and includes invasion of the uterus by the trophoblast as the initial step in placentation (Armant 2005). Trophoblast cells must adhere to the ECM, secrete ECM-degrading proteinases, and penetrate the remodeled matrix. Several proteolytic enzymes have been implicated in trophoblast invasion of the endometrium, including the PA/plasmin system (Strickland et al. 1976, Sappino et al. 1989, Teesalu et al. 1996, Zhang et al. 1996), MMPs (Peters et al. 1999, Whiteside et al. 2001, Chen et al. 2007), cathepsins (Afonso et al. 1997, 1999), and implantation-specific serine proteinases (Tang \& Rancourt 2005, Sharma et al. 2006, Oozono et al. 2008). Mouse embryos dramatically increase secretion of functional proteinases at implantation. The major proteinases secreted are urokinasetype plasminogen activator (PLAU; Strickland et al. 1976, Zhang et al. 1996) and MMP9 (92 kDa type IV collagenase; Behrendtsen et al. 1992, Peters et al. 1999, Whiteside et al. 2001, Chen et al. 2007). PLAU and MMP9 are expressed in primary trophoblast cells both in vitro and in vivo (Sappino et al. 1989, Harvey et al. 1995, Reponen et al. 1995, Teesalu et al. 1996, Das et al. 1997, Peters et al. 1999, Whiteside et al. 2001). 
Although Plau knockout mice are fertile, several lines of evidence indicate a role for this enzyme in the invasive process. Low implantation rates are associated with reduced PA activity (Aflalo et al. 2004, 2007). Failure of implantation is associated with reduced PA expression in embryos of the homozygous tw73 mouse mutant (Axelrod 1985). Moreover, general inhibitors of serine proteases block trophoblast invasion (Sun et al. 2007).

Trophoblast invasion in vivo is confined to the immediate pericellular environment and can be achieved by proteolytic enzymes secreted locally in discrete areas of cell-matrix contact (van Hinsbergh et al. 2006). PLAU binds with high affinity to a specific cell surface glycosylphosphatidylinositol-anchored receptor, PLAUR (Rijken \& Lijnen 2009). The binding of PLAU to its receptor enhances and directs its proteolytic activity; therefore, promoting efficient plasminogen activation and plasmin formation (Stahl \& Mueller 1995, Castellino \& Ploplis 2005, Rijken \& Lijnen 2009). PLAU expression appears to be regulated by trophoblast interactions with the ECM. Culture on fibronectin, fibronectin fragments, or laminin induces PLAU secretion by blastocysts, partially as a result of increased steady-state levels of Plau mRNA (Zhang et al. 1996). The proteolysis-stimulating activity of fibronectin is inhibited by hexapeptides containing the integrinrecognition sequence Arg-Gly-Asp.

Aside from its role in ECM remodeling, the binding of catalytically active or inactive PLAU to its receptor can stimulate cell proliferation, migration, and invasion (Alfano et al. 2005, Caceres et al. 2008). It has also been suggested that the cell surface-associated plasminogen/ plasmin system can activate or shed growth factors, including hepatocyte growth factor (Naldini et al. 1995, Mars etal. 2005, Matsuoka et al. 2006), latent transforming growth factor $\beta$ (Godar et al. 1999, Yehualaeshet et al. 1999, Leksa et al. 2005), basic fibroblast growth factor, dimeric platelet-derived growth factor-D (Ehnman et al. 2009), vascular endothelial growth factor (Noel et al. 2004, Lee et al. 2005), and heparin-binding epidermal growth factor-like growth factor (HBEGF; Guerrero et al. 2004, Roztocil et al. 2005, Caceres et al. 2008).

Although there are several studies that have investigated PLAU secretion, function, and localization during mouse peri-implantation development, understanding of the role of cell-associated PLAU and the events that regulate its expression during blastocyst implantation is incomplete. The purpose of this study was to analyze temporal changes in mRNA levels, cellular distribution, concentration, and secretion of PLAU during mouse blastocyst development in culture and its regulation by trophoblast interactions with ECM. Importantly, the question of whether exogenous plasminogen can induce the activation of pro-MMP9 secreted by mouse trophoblast cells was examined experimentally in light of MMP9 expression patterns.

\section{Results}

\section{Plau gene expression}

RT-PCR generated single bands at the expected sizes for both Plau (194 bp) and glyceraldehyde-3-phosphate dehydrogenase (Gapdh; 729 bp) mRNA with Plau band intensities that increased linearly between cycles 25 and 35 (Fig. 1A). The amount of Plau mRNA was estimated from densitometric scans of the amplicon bands, normalizing to the value obtained for Gapdh. Blastocysts expressed relatively low levels of Plau mRNA on gestation day (GD) 4. Thereafter, Plau mRNA expression increased until GD 8 in non-adhering embryos cultured on plates coated with BSA (Fig. 1B). Significantly higher levels of Plau mRNA were observed when the embryos were cultured on surfaces coated with type IV collagen or laminin $(P \leq 0.05$, compared with the embryos cultured on BSA; Fig. 2).
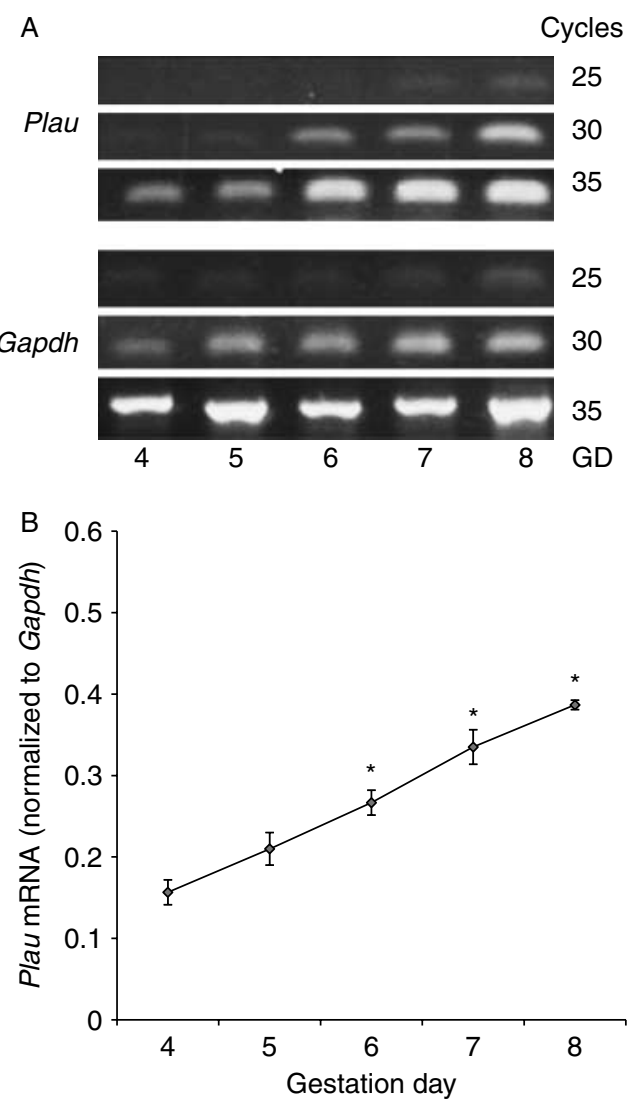

Figure 1 Temporal expression pattern of Plau mRNA during blastocyst development. Mouse blastocysts were cultured from GD 4 to GD 8 on non-adhesive plates coated with BSA and assessed for Plau mRNA. (A) Representative $1.2 \%$ agarose gels showing amplicons produced for Plau and Gapdh from total cellular RNA corresponding to 1.5 embryos. Cycling reactions were terminated after 25,30 , or 35 cycles, as indicated. (B) Densitometric analysis of bands produced after 30 cycles of amplification with relative pixel densities normalized to Gapdh. Means \pm s.E.M. from three independent experiments are shown. $* P<0.05$, relative to GD 4 . 

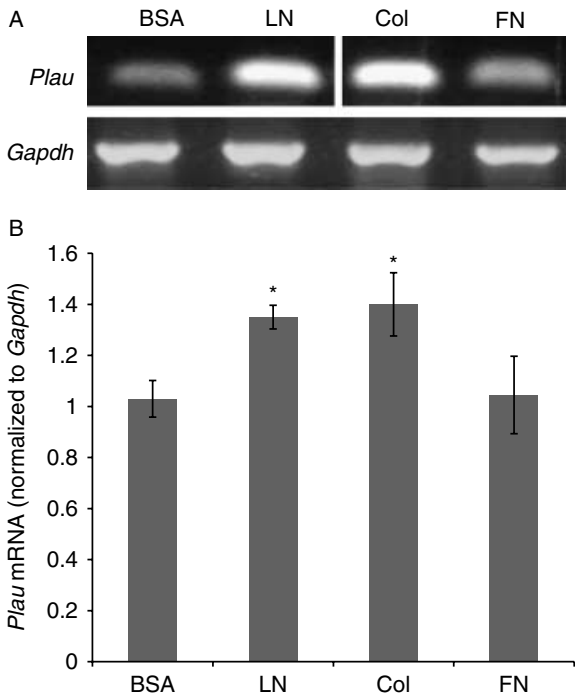

Figure 2 Effect of adhesion to ECM on Plau mRNA expression during trophoblast outgrowth. Blastocysts were cultured on BSA, fibronectin (FN), laminin (LN), or type IV collagen (Col) from GD 5 to GD 8. On GD 8, total RNA was extracted to estimate Plau or Gapdh mRNA, as in Fig. 1. (A) Representative gels of amplicons produced for Plau and Gapdh after 30 cycles of amplification. (B) Densitometric analysis of amplicon bands, normalized to Gapdh. Means \pm S.E.M. from three independent experiments are shown. ${ }^{*} P<0.05$, relative to culture on BSA.

\section{Cellular distribution of PLAU protein}

Immunofluorescence and confocal microscopy revealed PLAU at the apical cell surface of the mural trophoblast after blastocysts were cultured to GD 5; however, no stain was detected in earlier stage blastocysts (Fig. 3A). The antibody labeled non-permeabilized embryos comparably to those treated with detergent prior to staining (Fig. 3B), confirming PLAU localization on the trophoblast surface. The enzyme remained at the surface of giant trophoblast cells cultured until GD 8 on BSAcoated plates (Fig. 3A and B). When the embryos were cultured on fibronectin to permit trophoblast outgrowth, PLAU appeared on the surface of large rounded cells that appeared to be adherent trophoblasts (Fig. 3C), based on their size and because PLAU is considered a trophoblast marker (Strickland et al. 1976, Behrendtsen \& Werb 1997). However, it was absent from fully spread trophoblast giant cells at the periphery of the outgrowth (Fig. 3C). PLAU labeling of trophoblast cells outgrowing on fibronectin appeared more intense than that of nonadherent embryos.

\section{Analysis of PAs during blastocyst differentiation by zymography}

Zymography followed by densitometry was used for semi-quantification of enzyme activity in pooled conditioned embryo culture medium from GD 8 and GD 9, using human urinary PLAU as a standard (Fig. 4). Control zymograms developed without plasminogen produced no areas of casein lysis (data not shown). A linear response was observed between the integrated density and the concentration of enzyme standard (1.25-12.5 fg) or the amount of conditioned medium (recovered from 0.5 to 2 embryos). Up to four major bands of plasminogen-dependent caseinolytic activity were observed during peri-implantation development at the apparent molecular weights of 55, 40, 37, and $31 \mathrm{kDa}$, while the human urokinase produced a lytic zone primarily at $45 \mathrm{kDa}$ (Fig. 4A). Mouse PLAU is not glycosylated and, therefore, has a lower molecular weight than glycosylated human PLAU (Marshall et al. 1990). The $55 \mathrm{kDa}$ band corresponds with tissue-type plasminogen activator (PLAT), while the lower three bands are at the expected size of murine PLAU (McGuire \& Seeds 1989). Using similar methodology, PLAU and PLAT produced by mouse blastocysts have been detected at 38 and $52 \mathrm{kDa}$ respectively (Behrendtsen et al. 1992, Behrendtsen \& Werb 1997) or at 40 and $60 \mathrm{kDa}$ (Teesalu et al. 1996). Therefore, the $40 \mathrm{kDa}$ band represents the high-molecular weight two-chain form of PLAU, while the 37 and $31 \mathrm{kDa}$ bands are the result of its proteolytic processing. MMP3 can process human PLAU to a $31 \mathrm{kDa}$ form lacking the non-catalytic chain A. There is evidence that MMP3 is present in mouse blastocysts (Brenner et al. 1989), and that MMP3 or another enzyme catalyzes PLAU activation.

Zymography revealed the temporal pattern of PLAT and PLAU production and secretion during mouse embryo peri-implantation development (Fig. 5). Both PLAU and PLAT were present in embryonic tissues and conditioned medium, and were adsorbed to the culture surface. On GD 4 and GD 5, the major type of PA produced and secreted from blastocysts was PLAT. The PLAU triplet first appeared and became the major PA form on GD 6, increasing progressively until GD 9. Levels of PLAT in conditioned medium and cell extracts decreased on GD 6, and then increased in cell extract from GD 8 to 9. Zymograms from mouse embryos cultured on a non-adhesive substrate (BSA) or on fibronectin-coated plates were compared (Fig. 5). Similar patterns of enzyme accumulation were observed except for reduced PLAT in embryo lysates from blastocysts cultured on plates coated with fibronectin. This was also observed on laminin, but not on type IV collagen (data not shown). Densitometric analysis of PLAU in zymograms prepared from embryo-conditioned medium revealed comparable levels of PLAU production during development when blastocysts were cultured in the presence or absence of ECM, including laminin and type IV collagen (Fig. 6A). Accumulation of PLAU on GD 9 in embryo lysates, conditioned medium, or the substratum was unaffected by the presence of immobilized ECM (Fig. 6B). 
A
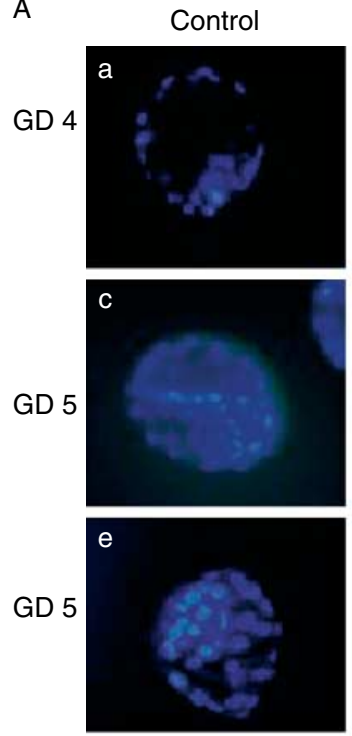

anti-PLAU
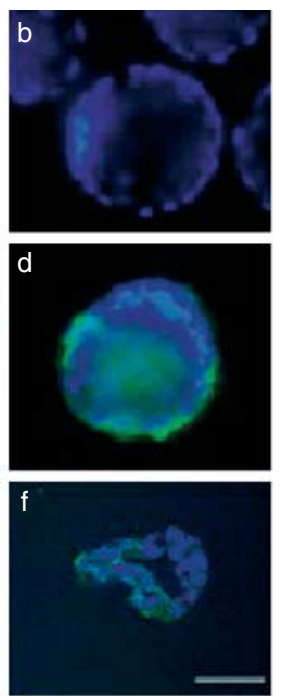

C
B
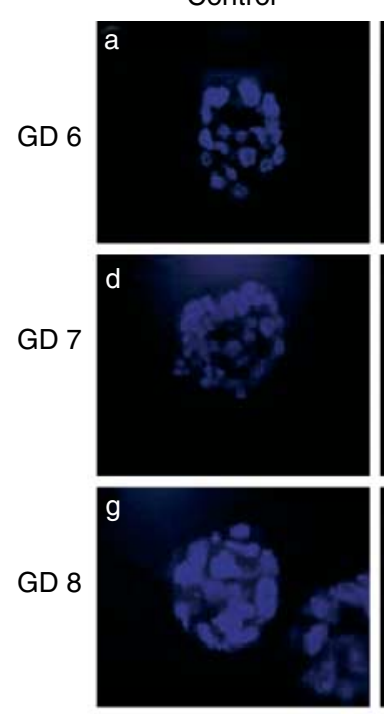

Permeabilized

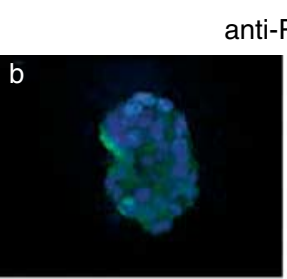

anti-PLAU
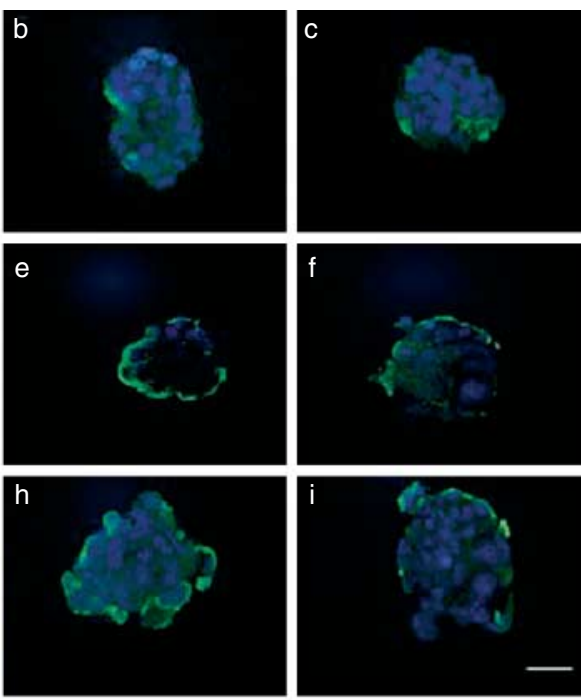

Non-permeabilized
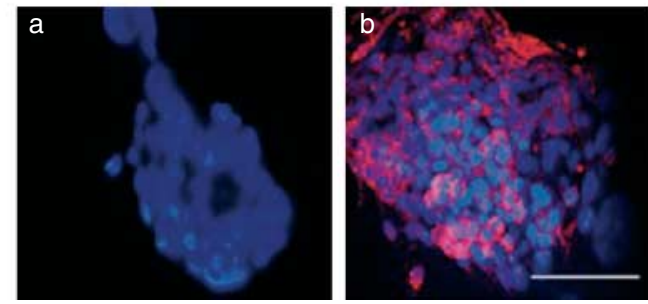

Figure 3 Immunofluorescence localization of PLAU in developing blastocysts. (A) Mouse blastocysts were labeled on GD 4 (a, b) and GD 5 (c-f) with either non-immune goat IgG (a, c, and e) or goat anti-PLAU antibody (b, d, and f) with DAPI counterstaining, as described in the Materials and Methods section. The images were obtained by fluorescence conventional (a, b, c, and d) or confocal (e and $\mathrm{f}$ ) microscopy. (B) Non-adhering mouse blastocysts were cultured on BSA-coated surfaces until GD $6(\mathrm{a}-\mathrm{c})$, GD 7 (d-f), or GD 8 (g-i) and labeled with either non-immune goat IgG (a, d, and g) or goat antiPLAU antibody (b, c, e, f, h, and i), as in (A), before imaging by confocal microscopy. Prior to labeling, embryos were either permeabilized with detergent ( $a, b, d, e, g$, and h) or non-permeabilized to restrict labeling to the cell surface (c, f, and i). (C) Mouse blastocysts cultured to GD 8 on fibronectin (FN) were labeled with either non-immune goat IgG (a) or goat anti-PLAU antibody (b), as in (A). Nuclei appear blue, and fluorescein- or Texas Redconjugated secondary antibody appears green $(\mathrm{A}$ and $\mathrm{B}$ ) or red $(\mathrm{C})$. At least ten embryos were examined in each treatment group. Bar $=50 \mu \mathrm{m}$.

\section{Plasminogen-dependent MMP9 activation}

Considering that mouse blastocysts produce PLAU and pro-MMP9 in the culture, it was hypothesized that activated embryonic PLAU can use plasminogen to generate plasmin, which can proteolytically activate MMP9. Therefore, embryos were cultured for $48 \mathrm{~h}$ beginning on GD 7 in the absence or presence of 5, 10, or $20 \mu \mathrm{g} / \mathrm{ml}$ human plasminogen. On GD 9, MMP9 in the conditioned medium was assessed by gelatin zymography. As a control, medium without embryos was incubated with plasminogen and processed similarly. The addition of plasminogen resulted in the activation of MMP9 (Fig. 7A). Conditioned medium from embryos cultured without plasminogen produced only the zymogenic form of MMP9 (105 kDa). In the presence of $5-20 \mu \mathrm{g} / \mathrm{ml}$ plasminogen, embryos produced an additional gelatinolytic band at $88 \mathrm{kDa}$. A band with similar electrophoretic migration was observed with embryo-conditioned medium obtained on GD 9 and treated with $p$-aminophenyl mercuric acetate (APMA).
Production of the $88 \mathrm{kDa}$ form was inhibited by $\alpha 2$-antiplasmin (data not shown). Concomitantly, plasmin activity measured in the conditioned medium increased proportionally to the plasminogen concentration, and its activity required the presence of embryos (Fig. 7B). Amiloride, a specific PLAU inhibitor (Vassalli \& Belin 1987), reduced the ability of embryo-conditioned medium (GD 9) to convert plasminogen to plasmin by $90 \%(P<0.05)$, and its addition with plasminogen to live embryo cultures caused a $60 \%(P<0.05)$ inhibition of plasmin production (data not shown). The milder effect of amiloride in live cultures could reflect its reduced effectiveness when PLAU is bound to cell surfaces (Dyer et al. 2002).

\section{MMP9 expression}

MMP9 expression was examined to determine if it was coordinately regulated with PLAU, since the latter enzyme may be required for MMP9 activation. RT-PCR 

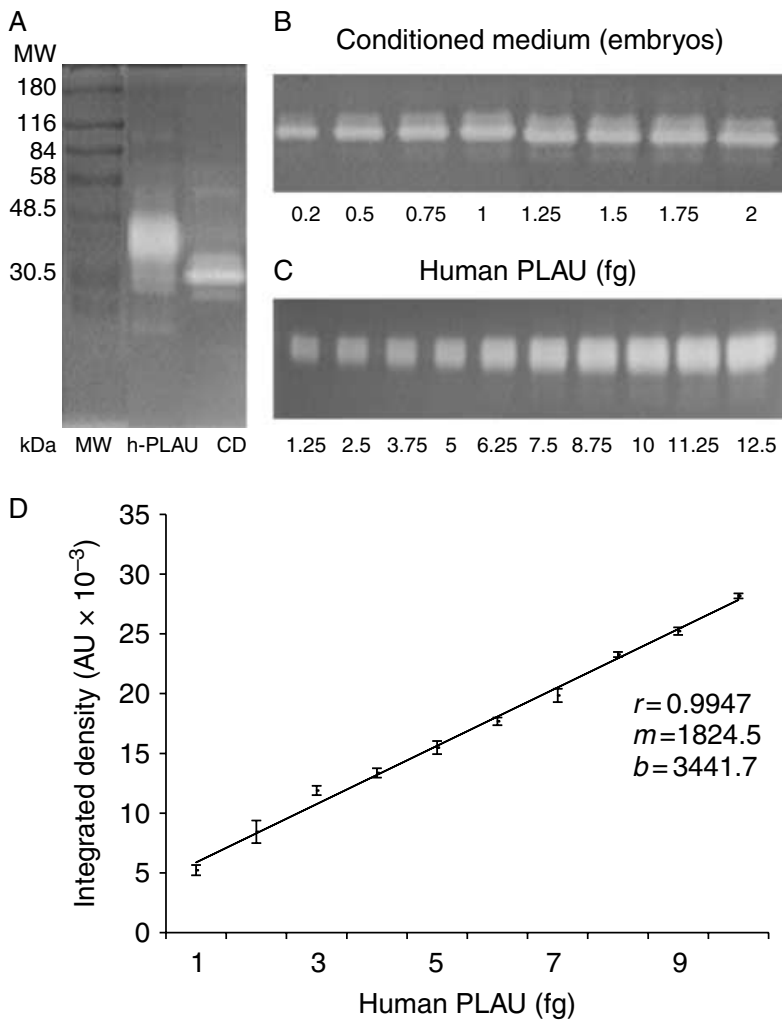

Figure 4 Plasminogen-casein zymography of conditioned medium. (A) Human PLAU (hPLAU) and conditioned medium from embryos cultured to GD 9 (CD) were analyzed by plasminogen-casein zymography, along with molecular weight (MW) markers. (B-D) Varying amounts of blastocyst-conditioned medium (B) or hPLAU standard $(C)$ were analyzed by the same procedure and semi-quantified by densitometric analysis (D). Data are presented as the mean and S.E.M. from three experiments. Results of a linear regression are shown in the graph.

with primers of $\mathrm{Mmp9}$ generated a single amplicon at the expected size that increased linearly up to 40 cycles, as estimated by densitometric scanning. Mmp9 mRNA levels, estimated after 35 cycles of amplification and normalized to Gapdh mRNA, increased linearly between GD 4 and GD 8 in non-adhering blastocysts (Fig. 8A and B). Gelatin zymography revealed five bands (230, 165, 105, 97, and $87 \mathrm{kDa}$ ) of EDTA-sensitive gelatinolytic activity in peri-implanting mouse embryos that first, and most strongly, appeared in the conditioned medium on GD 5 and increased progressively until GD 9 in both medium and embryo lysates (Fig. 8C). The number of embryo equivalents of the culture medium loaded on the zymograms was reduced at later times to prevent overloading. The $165 \mathrm{kDa}$ band has not been characterized. The $230 \mathrm{kDa}$ band, present in both medium and embryonic lysates, could represent the homodimeric form of MMP9 (Goldberg et al. 1992, Olson et al. 2000), while bands of 97 and $87 \mathrm{kDa}$ correspond to the non-glycosylated precursors, partially active forms or fully active forms of the enzyme. As shown in Fig. 7A, APMA converts the $105 \mathrm{kDa}$
pro-MMP9 (Tanaka et al. 1993, Reponen et al. 1995) to an active $87 \mathrm{kDa}$ species. Embryo-conditioned medium contained a major $105 \mathrm{kDa}$ band, while the $97 \mathrm{kDa}$ band appeared only occasionally on GD 6 (Fig. 8C). However, embryonic lysates contained bands of 105, 97, and $87 \mathrm{kDa}$.

\section{Discussion}

The expression of PLAU and its role in MMP regulation during blastocyst differentiation was investigated, revealing the progressive accumulation of PLAU between GD 4 and GD 9. Expression of Plau mRNA increased from GD 4 to GD 8, while protein levels first appeared on the surface of mural trophoblast cells on GD 5. Zymographic detection of PLAU secretion into the culture medium commenced on GD 6, increasing until GD 9. Expression of Plau mRNA was stimulated when type IV collagen or laminin was present, but PLAU protein levels were apparently unaffected by an ECM substrate.

Similar patterns of PLAU expression during the development of cultured mouse blastocysts have been described using an enzymatic assay (Strickland et al. 1976, Sellens \& Sherman 1980, Zhang et al. 1996), but the enzyme was assessed only in the conditioned medium or the lytic zone around the embryo. Although we used the same primers as Harvey et al. (1995) to estimate Plau mRNA, we detected it a day earlier (GD 4), probably due to differences in the mRNA extraction procedure. In both studies, however, Plau mRNA expression increased sharply on GD 6, suggesting transcriptional activation around the time of blastocyst hatching, as it prepares for implantation. The Plau promoter contains binding sites for activator proteins 1

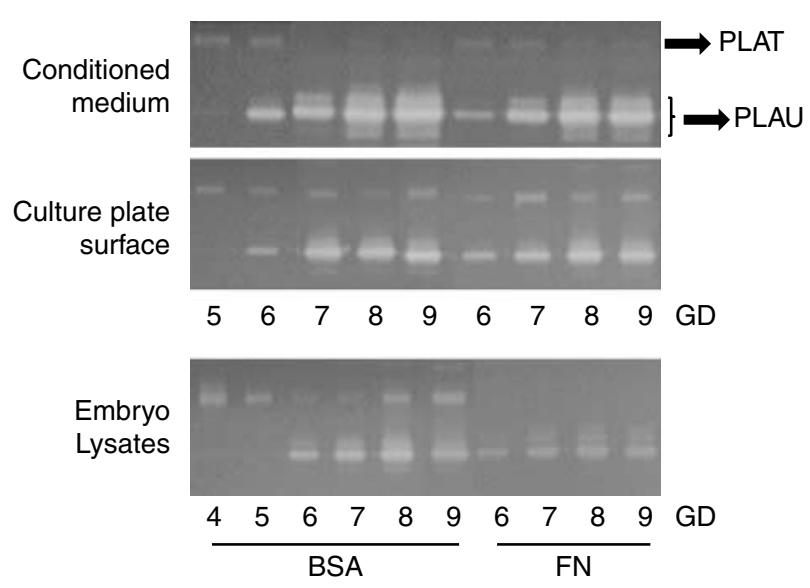

Figure 5 Temporal pattern of PA proteins during development. Plasminogen-casein zymography of conditioned medium, extracts of protein adsorbed to the culture plate surface, and embryo lysates was conducted on the indicated days of gestation, using blastocysts cultured on plates coated with BSA or fibronectin (FN). Assays used two embryo equivalents for conditioned medium and three embryo equivalents for adsorbed proteins or lysates. The zymograms are representative of at least three separate experiments. 

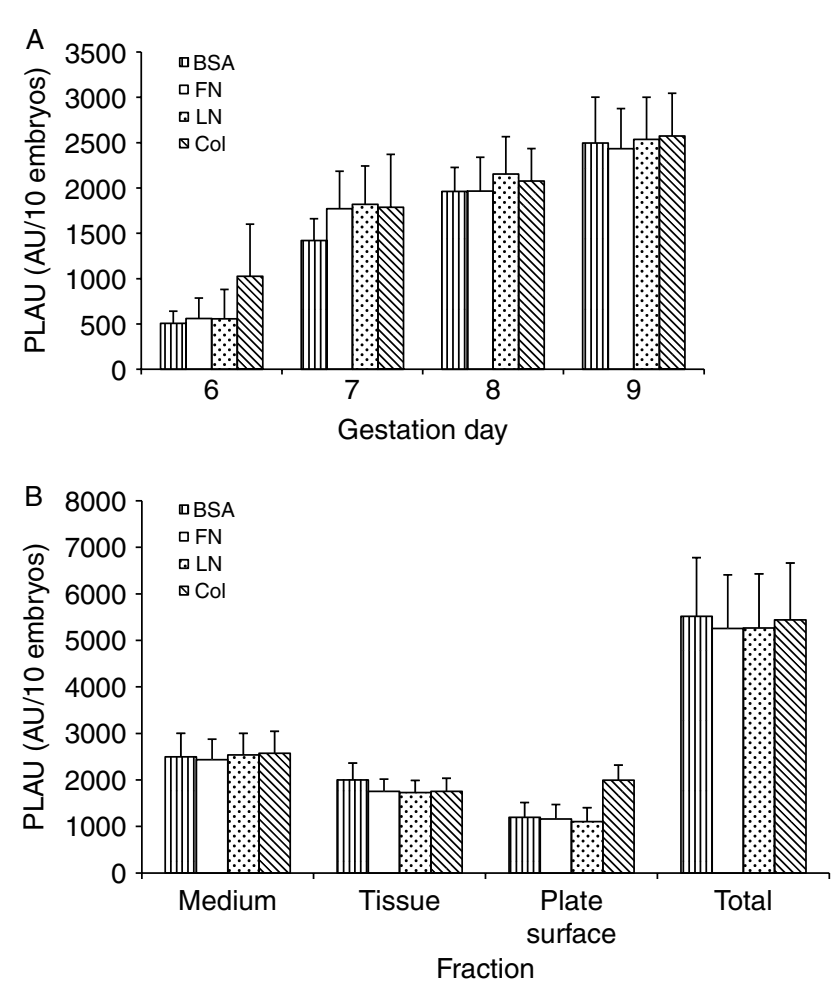

Figure 6 Influence of ECM on PLAU secretion during blastocyst development. Mouse blastocysts were cultured on plates coated with BSA, laminin (LN), fibronectin (FN), or type IV collagen (Col), as indicated. (A) The secretion of PLAU was analyzed daily in conditioned medium by plasminogen-casein zymography and densitometry. (B) On GD 9, medium conditioned during the final $24 \mathrm{~h}$ (MEDIUM), detached embryos (TISSUE), and proteins adsorbed to the culture surface (PLATE SURFACE) were recovered and analyzed for PLAU by plasminogencasein zymography and densitometry. Data are presented as the mean and S.E.M. from three experiments. There were no statistically significant differences among the four groups in either experiment.

(TCFAP1) and 2 (TCFAP2; Cassady et al. 1991). Tcfap2c is expressed at high levels in mouse trophectoderm and giant trophoblast cells, and it is upregulated during differentiation of trophoblast stem cells (Kuckenberg et al. 2010). During implantation, Tcfap2c expression is restricted to the extra-embryonic lineages and deletion of the gene disrupts trophoblast development (Auman et al. 2002). Elimination of the transcription factor Ets2, which is also expressed specifically in the trophoblast at implantation and required for trophoblast development, leads to failure in MMP9 expression and persistence of ECM restricting trophoblast invasion (Yamamoto et al. 1998). Both Mmp9 and Plau utilize Ets-binding sites and could be coordinately regulated in the trophoblast.

The other PA, PLAT, was also detected by gel zymography in the conditioned medium and embryo extracts. PLAT was initially more prominent than PLAU but was then overtaken as PLAU expression progressively increased after GD 6 . In the first 2 days, PLAT from maternal oviductal fluid was probably bound to the blastocyst surface (Carroll et al. 1993) and released into the medium. Furthermore, PLAT can be produced by parietal endodermal cells (Strickland et al. 1976), which first appear and proliferate beginning on GD 5 (Behrendtsen \& Werb 1997).

\section{Cell surface location of PLAU}

The localization of PLAU on the external surface of mouse trophoblast cells was confirmed by confocal microscopy in fixed, non-permeabilized embryos. In mouse blastocysts, PLAU was initially detected on the surface of mural trophoblast cells (GD 5). In contrast, PLAU has been observed at all the stages of rat preimplantation development, and it is present both in the cytoplasm and on the surface of trophectoderm at the early blastocyst stage (Aflalo et al. 2005, 2007). However, PLAU distribution in adherent rat blastocysts has not been studied.

Peri-implanting mouse embryos express a specific membrane receptor for PLAU (PLAUR; Harvey et al. 1995, Teesalu et al. 1996). The zymogenic and active forms of PLAU are bound to PLAUR through the
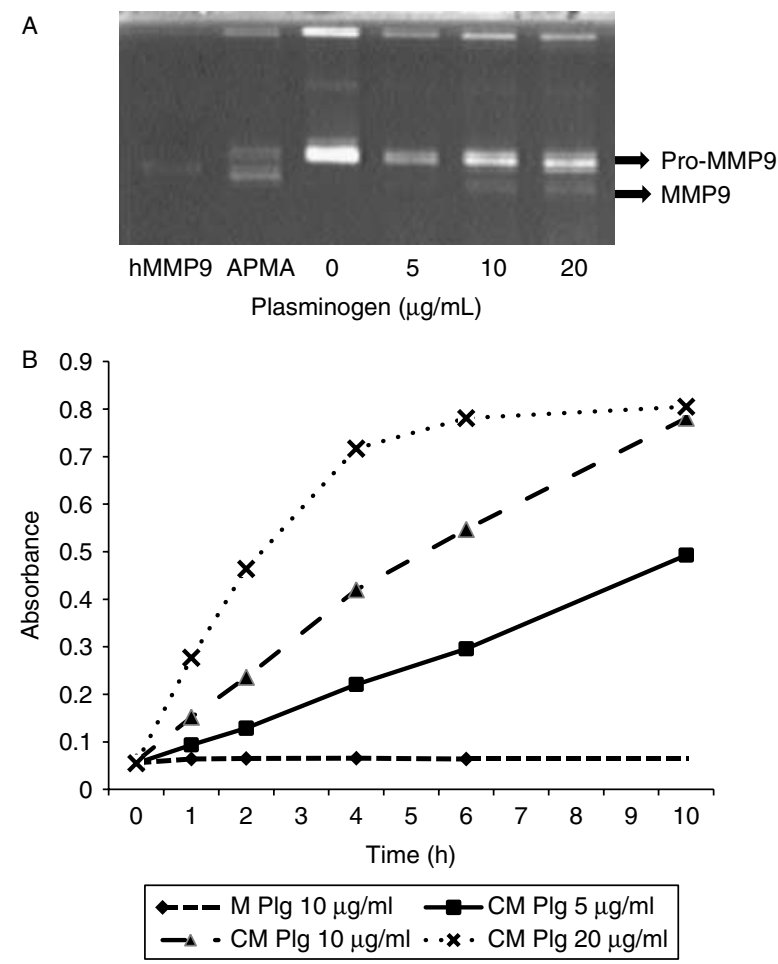

Figure 7 Plasminogen-mediated activation of MMP9. Mouse blastocysts were cultured from GD 7 to GD 9 in medium containing $0,5,10$, or $20 \mu \mathrm{g} / \mathrm{ml}$ plasminogen, and the conditioned medium was processed by gelatin zymography. (A) Zymograms of human pro-MMP9 (hMMP) and blastocyst-conditioned medium. Conditioned medium (no plasminogen) was treated with APMA to activate MMP9 (APMA). The presence of plasminogen during embryo culture activated MMP9 with a dose dependency. (B) Plasmin activity was measured in medium containing plasminogen (Plg, as indicated) after 2 days of culture either without $(\mathrm{M})$ or with $(\mathrm{CM})$ blastocysts. 
A

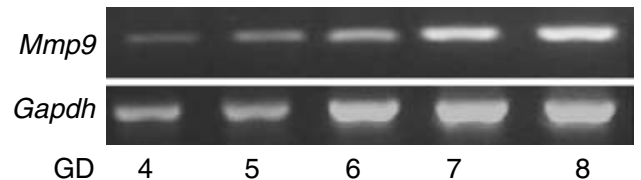

B

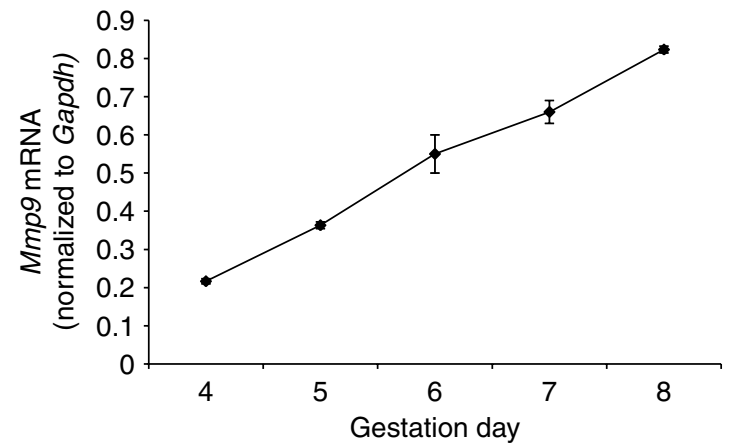

C

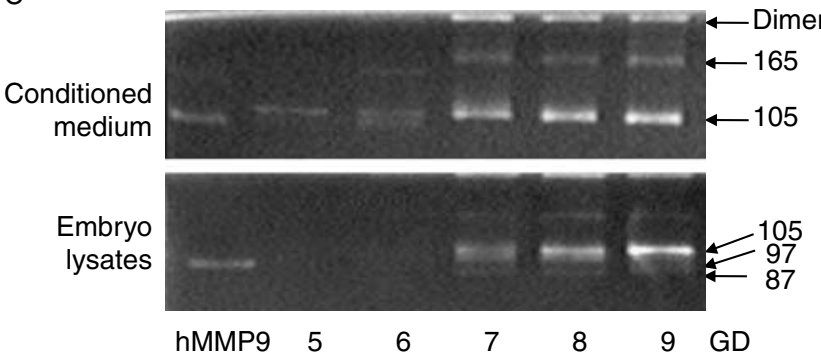

Figure 8 MMP9 expression during blastocyst development. Blastocysts were cultured to the indicated gestation day (GD), and Mmp9 and Gapdh mRNA were amplified by RT-PCR (A) and then quantified by densitometry to determine the developmental pattern of Mmp9 mRNA (B), or the conditioned medium and embryo lysates were analyzed by gelatin zymography $(\mathrm{C})$, as described in the Materials and Methods.

Means and S.E.M. from three independent experiments are shown in (B). Conditioned medium equivalent to 100, 25, 8, 3, and 3 embryos was used on GD 5, 6, 7, 8, and 9 respectively for zymography shown in (C). All lysate samples contained 12 embryo equivalents. Human MMP9 (hMMP9) was used as reference. All zymograms shown are representative of three or more separate experiments.

non-catalytic $A$ chain of the active enzyme or the $\mathrm{NH}_{2}$-terminal portion of the single-chain proenzyme (Quax et al. 1998). It has been observed that PLAU bound to PLAUR on the cell surface activates plasminogen more efficiently than the soluble enzyme (Ellis et al. 1991). Therefore, the peri-implanting blastocyst can form plasmin beginning on GD 5, approximately the time in vivo when the embryo binds to the luminal epithelium. At that time, PLAU could participate in focalized proteolysis of ECM in the vicinity of trophoblast cells. Membrane-associated proteolytic systems contribute significantly to trophoblast invasion of the endometrium (Cohen et al. 2006, Fujiwara 2007).

Cell surface PLAU could facilitate communication between fetal and maternal cells by activating pro- forms of intercellular signaling molecules, either directly or indirectly as part of a protease cascade. Of particular interest is HBEGF, which is expressed specifically by luminal epithelial cells adjacent to the blastocyst at the beginning of GD 5 (midnight) and appears to have a critical role during implantation (Das et al. 1994, Lim \& Dey 2009). Like other members of the EGF family, HBEGF is initially produced as a transmembrane protein that is secreted through the cleavage and shedding of its extracellular domain by a metalloproteinase. HBEGF and its receptors are expressed in both trophoblast and uterine epithelium, and expression of the transmembrane form of HBEGF is considered the earliest molecular response of uterine epithelium to blastocyst signals (Jessmon et al. 2009, Lim \& Dey 2009). Acceleration of blastocyst differentiation in vitro is dependent upon HBEGF shedding in GD 5 mouse embryos (Liu \& Armant 2004), possibly through the contribution of PLAU to the proteolytic activation of the HBEGF sheddase. It has been demonstrated in cancer cells that PLAU induces HBEGF shedding and transactivation of its receptor through a process mediated by MMPs (Guerrero et al. 2004), possibly MMP9 (Lucchesi et al. 2004, Hurtado et al. 2007), and that PLAU can induce the expression of HBEGF (Caceres et al. 2008).

\section{PA adsorption to the culture surface}

All forms of PA secreted by trophoblast cells were consistently bound to the culture surface, even when exogenous adhesive substrates were not added. In the latter case, this may be attributed to ECM or other proteins produced by the embryos that become immobilized in the substratum. The polystyrene Petri dishes used for embryo culture avidly bind proteins, including those exposed to the dishes before embryo culture. These proteins and others secreted by embryonic cells during the culture reversibly adhere to polystyrene to create a matrix that binds secreted proteins, often through specific protein-protein interactions. Both PLAT and PLAU binding to the culture surfaces are dependent on cell type (Stack et al. 1994), and both have been found associated with ECM produced by cultured fibroblasts, neurons, and endothelial cells (Krystosek \& Seeds 1986, Korner et al. 1993). The binding of PLAT to laminin and fibronectin has been described previously as specific and saturable. PLAT binds to the amino-terminus of fibronectin or the carboxy-terminal globular domain of the laminin $\alpha$ chain (Salonen et al. 1985, Moser et al. 1993, Goldfinger et al. 1998). The binding of PLAU to ECM has been less studied and was found to be weakly associated with fibronectin (Salonen et al. 1985) or laminin (Goldfinger et al. 1998). Our data indicate that ECM produced by the peri-implanting mouse blastocyst has a high capacity for PA binding. This binding may increase the transformation of plasminogen to plasmin (Stack et al. 1990, 1994). While type IV collagen is resistant to plasmin cleavage, both laminin and fibronectin are degraded by plasmin (Goldfinger et al. 1998, Bonnefoy \& Legrand 2000, Uemura et al. 2005). 
ECM interacts with plasminogen/plasmin through a lysine-binding site-dependent interaction (Moser et al. 1993), thereby protecting plasmin from certain inhibitors and proteases to prolong its proteolytic activity (Knudsen et al. 1986). In fluid phase, plasmin is rapidly inactivated by inhibitors. Modulation of plasminogen activation by ECM proteins may be an important regulatory mechanism during ECM proteolysis associated with cell invasion. ECM-growth promoting and thrombogenic properties are modulated by PAs and plasmin through the release of ECM-bound growth factors and activation of proenzymes like pro-MMP9 and prothrombin (Stack et al. 1990, 1994, Korner et al. 1993).

\section{Developmental regulation of PLAU expression and ECM interactions}

Our findings are consistent with the idea that temporal PLAU expression is regulated by an intrinsic program during blastocyst development and quantitatively modulated by interactions with ECM proteins, principally type IV collagen. Under serum-free conditions and in the absence of exogenous ECM, PLAU was expressed in a temporal pattern similar to that observed under adherent conditions, consistent with previous work (Sellens \& Sherman 1980), and paralleled the developmental pattern in vivo (Teesalu et al. 1996). Zhang et al. (1996) found that ECM interactions increase PLAU expression in cultured mouse blastocyst. The present investigation only partially corroborates that data, since fibronectin did not have a stimulating effect. Although the labeling of PLAU by immunofluorescence in embryos outgrowing on fibronectin appeared stronger than that of blastocysts cultured on a non-adhesive substrate, semi-quantitative analysis of PLAU zymography suggested otherwise. There was no significant difference in PLAU proteolytic bands in embryo lysates, conditioned medium, or proteins adsorbed to the culture plate under non-adherent or adhesion-promoting conditions. If there was, indeed, elevated cell surface PLAU in embryos outgrowing on fibronectin, it did not result in greater accumulation in the medium where the greater portion of the enzyme was detected. The different results reported here and elsewhere could be due to differences in experimental conditions or contamination of ECM proteins with proteases or growth factors. Zhang et al. (1996) used a colorimetric PLAU assay under conditions that could be influenced by endogenous PA inhibitor (PAI). The zymographic procedure used in the present investigation disrupts the interaction of PLAU with its inhibitor. It is, therefore, possible that ECM regulates PLAU activity predominantly through PAI. The role of PAI in mouse trophoblast invasion merits further investigation.

Since deficiency of Plau or Mmp9 does not impair embryo implantation (Bugge et al. 1995), other proteases may be required during trophoblast invasion.
Additionally, the overlapping functions of several ECM-degrading proteases may compensate for the loss of any one of them. A role for maternal PLAT acting upon the embryo or ECM cannot be excluded. The role of serine proteinases (Tang \& Rancourt 2005) or other MMPs, including MMP3, MMP1/collagenase I (Brenner et al. 1989, Chen et al. 2007), stromelysin-3/ MMP11 (Lefebvre et al. 1995), or MMP14/MT1-MMP (Tanaka et al. 1998), likely contributed to trophoblast invasion either through their direct ECM-degrading activity or through activation of other proteases within a proteolytic cascade.

\section{Developmental regulation of MMP9 expression}

Transcription, translation, and secretion of MMP9 increased progressively during blastocyst development in parallel to PLAU. Gelatin zymography indicated that the active form of MMP9 was not secreted into the medium, although the $87 \mathrm{kDa}$ form was present in embryo lysates. The $97 \mathrm{kDa}$ protein, also found in embryos, may represent an intermediate in MMP9 activation. Two groups (Behrendtsen et al. 1992, Whiteside et al. 2001) have reported the presence of the active form of MMP9 in medium conditioned by developing mouse embryos cultured with either serum or a Matrigel substrate. The contribution of serum or Matrigel components (proteinases or growth factors) cannot be excluded, as Matrigel contains plasminogen (Farina et al. 1996), PAs, MMP2, and MMP9 (Mackay et al. 1993). When Matrigel is reconstituted by incubation at $37^{\circ} \mathrm{C}$, plasmin is formed, and MMP9 activation can be induced (Farina et al. 1996). Decreased PLAU activity has been observed in embryos developing in vitro compared with embryos developing ex vivo, suggesting that the activation of both proteases could be deficient in vitro due to a lack of maternal factors (Aflalo et al. 2005). Here, we have explored the potential role of the plasminogen/plasmin cascade in blastocyst MMP9 activation, which may better reflect circumstances in utero.

\section{Plasminogen activation and MMP9 activation}

PLAU function during embryo implantation appears to depend on the generation of plasmin, leading to the degradation of ECM components either directly or indirectly through the activation of MMP9 zymogen. The findings that the temporal pattern of MMP9 expression paralleled that of PLAU, that plasmin was generated after addition of plasminogen to the embryo culture, and that exogenous plasminogen induced the activation of MMP9 are, in fact, consistent with the existence of a proteinase cascade involving both the plasminogen/plasmin system and metalloproteinases to facilitate trophoblast invasion of the endometrium. 
There is a marked increase in uterine vascular permeability on GD 5 in mice associated with the release of plasma proteins, including plasminogen, into the luminal fluid (Rockwell et al. 2002). These data suggest that maternal-embryonic interactions are required for protease activation during blastocyst implantation, with plasminogen having a key role. Furthermore, plasmin can degrade some ECM proteins, including soluble and immobilized fibronectin (Liotta et al. 1981, Hantai \& Festoff 1987), and laminin (Uemura et al. 2005).

The physiological pathway for efficient MMP9 activation is unclear. Its activation requires proteolytic processing of the amino-terminal domain that can be initiated by several enzymes, including plasmin and stromelysin-1 (MMP3). The addition of plasmin to conditioned medium of GD 8 mouse blastocysts failed to activate MMP9 (Behrendtsen et al. 1992). However, the activation of MMP9 by plasmin in solution is very inefficient (Goldberg et al. 1992) because of plasmin instability, and MMP3 has been considered as the physiological activator of MMP9 (Goldberg et al. 1992, Olson et al. 2000). Whether plasmin can convert proMMP9 to its active form is a subject of debate. Efficient activation of MMP9 by plasmin is obtained with cellbound substrates (Mazzieri et al. 1997). Accordingly, in our experiments, PAs are bound to the cell and culture surfaces. In agreement with our findings, the addition of plasminogen induces pro-MMP9 activation in macrophages obtained from Mmp3-deficient mice (Lijnen et al. 1998). Additionally, plasminogen-dependent MMP9 activation is required for inflammatory macrophage migration (Gong et al. 2008). We cannot exclude the possibility that pro-MMP9 activation can be mediated by stromelysin-1, but we have demonstrated that maternal plasminogen can fulfill this key regulatory function during trophoblast invasion. It has been proposed that the combined action of plasminogen/plasmin and MMPs is essential for proper placental development and function (Solberg et al. 2003), particularly in the regulation of placental vascularization and decidual differentiation. The plasminogen-dependent activation of MMP9 that we report in late blastocysts is consistent with this suggestion and can partially explain how both enzyme systems interact in vivo.

In conclusion, the temporal pattern of PLAU expression in the blastocyst is dependent primarily on the intrinsic developmental program and is enhanced quantitatively through cellular interactions with laminin or type IV collagen. In light of our observation that cultured blastocysts secrete predominantly proMMP9 in the absence of serum, these findings suggest that developing blastocysts produce increased levels of both PLAU and latent MMP9 during the periimplantation period, while execution of the plasminogen/ MMP proteolytic cascade requires maternal provision of plasminogen.

\section{Materials and Methods}

\section{Production and culture of embryos}

Mouse embryos were generated from 5 to 8-week-old female CF1 mice (Charles River Laboratories, Willmington, MI, USA) that were superovulated and mated with fertile B6SJL/J males (Jackson Laboratory, Bar Harbor, ME, USA), as described previously (Armant 2006). Blastocysts were collected on GD 4, where the vaginal plug was observed on the morning of GD 1. Uterine horns were removed and flushed with M2 medium (Sigma Chemical Co.), and the embryos were recovered under a Wild M3 stereo dissecting microscope (Leica, Wetzlar, Germany).

Groups of four embryos were cultured under mineral oil, in $5 \mu \mathrm{l}$ drops of Ham's F10 medium (Gibco BRL) containing $1 \mathrm{mg} / \mathrm{ml}$ BSA, $2.2 \mathrm{mM}$ calcium lactate, $12.5 \mathrm{mM} \mathrm{NaHCO}$, $100 \mathrm{U} / \mathrm{ml}$ penicillin, and $0.1 \mathrm{mg} / \mathrm{ml}$ streptomycin at $37^{\circ} \mathrm{C}$ using a $5 \% \mathrm{CO}_{2}$ /air incubator. Polystyrene Petri dishes (number 1008; Falcon, Lincoln Park, NJ, USA) were coated overnight at $4{ }^{\circ} \mathrm{C}$ with ECM proteins by applying medium containing $100 \mu \mathrm{g} / \mathrm{ml}$ of mouse laminin (Sigma), human type IV collagen, or human fibronectin (Gibco BRL). The next day, they were washed five times with culture medium and equilibrated in an incubator before adding embryos.

Blastocyst cultures were inspected daily between noon and $1400 \mathrm{~h}$ with a dissecting microscope to determine the percentage of embryos with trophoblast outgrowth, as detailed elsewhere (Armant 2006). The conditioned medium was harvested and replaced with fresh medium every $24 \mathrm{~h}$. Attached or outgrowing embryos were physically detached with a flamepolished capillary tube (Sellens \& Sherman 1980). Nonadherent and detached embryos were collected, rinsed five times in the culture medium, and lysed in $1 \times$ non-reducing electrophoresis sample buffer. The culture dish surface, after removing embryos, was washed five times with medium, and the adsorbed proteins were extracted with $1 \times$ non-reducing electrophoresis sample buffer. For examination of trophoblast outgrowths by immunofluorescence, blastocysts were cultured to GD 5, transferred to eight-well chamber slides (Lab-Tek, NUNC, Naperville, IL, USA), and then cultured to GD 8.

\section{Analysis of $m R N A$}

Total RNA was extracted from groups of 12 mouse embryos or blastocyst outgrowths using RNeasy kit (Qiagen). RNA was reverse transcribed and PCR was performed using a one-step RT-PCR kit (Qiagen). RT-PCR analysis of Gapdh mRNA, which was used as control, was performed for RNA integrity and accuracy of loading.

Specific primers used for RT-PCR of Plau, Mmp9, and Gapdh mRNA were sense 5'-GTGCCGCACACTGCTTCATT-3' and antisense 5'-CGTGCTGGTACGTATCTTCA-3' (Harvey et al. 1995); sense 5'-TTGAGTCCGGCAGACAATCC-3' and antisense 5'-CCTTATCCACGCGAATGACG-3' (Harvey et al. 1995); and sense 5-'GTATGTCGTGGAGTCTACTG-3' and antisense 5'-TACTCCTTGGAGGCCATGTA-3' (Ogawa et al. 2000) respectively. The RT reaction was conducted for $30 \mathrm{~min}$ at $50{ }^{\circ} \mathrm{C}$. Reverse transcriptase was inactivated, and HotStar Taq DNA polymerase was activated at $95^{\circ} \mathrm{C}$ for $15 \mathrm{~min}$. 
The amplification reaction included 25-35 cycles of heat denaturation at $94{ }^{\circ} \mathrm{C}$ for $45 \mathrm{~s}$, followed by annealing of the primers for $45 \mathrm{~s}$ at $62{ }^{\circ} \mathrm{C}$, and extension for $1 \mathrm{~min}$ at $72{ }^{\circ} \mathrm{C}$. After the final cycle, the temperature was maintained at $72{ }^{\circ} \mathrm{C}$ for $10 \mathrm{~min}$. PCR-amplified products were examined using $1.2 \%$ agarose gel electrophoresis and ethidium bromide staining. DNA bands were photographed, and the ratio of band intensity relative to Gapdh was estimated by scanning densitometry using the Image (NIH, Bethesda, MD, USA) image analysis program. Because quantitative application of this method is contingent on the analysis of the PCR products during the amplification phase, before reaching the plateau, cycle relationships and dilution curves for RNA samples were determined empirically.

\section{Immunofluorescence microscopy}

Mouse embryos were fixed for $30 \mathrm{~min}$ at room temperature in PBS containing 3\% paraformaldehyde and then incubated for $10 \mathrm{~min}$ in $0.15 \mathrm{M}$ glycine, $\mathrm{pH}$ 7.2. Some embryos were permeabilized with $0.1 \%$ Triton $\mathrm{X}-100$ for $10 \mathrm{~min}$ at room temperature. Embryos were rinsed through five drops of PBS containing $10 \mathrm{mg} / \mathrm{ml}$ BSA (PBS/BSA) and then incubated overnight at $4{ }^{\circ} \mathrm{C}$ with $10 \mu \mathrm{g} / \mathrm{ml}$ of purified goat polyclonal antibody against the carboxy-terminal domain of human PLAU (Santa Cruz Biotechnology, Inc., Santa Cruz, CA, USA) in PBS/BSA. Primary antibody control was $10 \mu \mathrm{g} / \mathrm{ml}$ non-immune goat IgG (Jackson ImmunoResearch Laboratories, West Grove, PA, USA). Primary antibodies were detected using $10 \mu \mathrm{g} / \mathrm{ml}$ fluorescein- or Texas Red-conjugated rabbit anti-goat IgG (Jackson), and nuclei were stained with $10 \mu \mathrm{g} / \mathrm{ml} 4^{\prime}, 6^{\prime}$ diamino-2-phenylindole $\mathrm{HCl}$ (DAPI; Calbiochem, La Jolla, CA, USA). Embryos were incubated with a cocktail of secondary antibody and DAPI at $37^{\circ} \mathrm{C}$ for $60 \mathrm{~min}$, rinsed, mounted on slides with permanent mounting medium (Chemicon, Tamecula, CA, USA), and stored in the dark at $4{ }^{\circ} \mathrm{C}$. Antigens labeled with Texas Red (red) or fluorescein (green) and nuclei stained with DAPI (blue) were viewed in a Zeiss (Thornwood, NY, USA) 310 confocal scanning laser microscope, using excitation wavelengths of 543, 488, and $364 \mathrm{~nm}$ respectively. Images presented are representative of at least ten embryos that produce similar staining patterns.

\section{Zymography}

Plasminogen-dependent caseinolytic activity in the conditioned medium, cell lysates, and proteins adsorbed to the culture surfaces were studied by substrate gel electrophoresis (Legrand et al. 2001), to determine the presence of PAs and their molecular weights. Samples corresponding to 2.5-8 embryo equivalents were resolved by electrophoresis under non-denaturing conditions in $10 \%$ polyacrylamide-SDS gels containing $1 \mathrm{mg} / \mathrm{ml}$ bovine $\alpha$-casein (Sigma Chemical Co.) and $10 \mu \mathrm{g} / \mathrm{ml}$ human plasma plasminogen (528175, Calbiochem). Prestained molecular weight markers 27-180 (SDS-7B, Sigma) were run on the same gels for molecular weight estimation. After electrophoresis, the gels were washed twice for $30 \mathrm{~min}$ in $2 \%(\mathrm{v} / \mathrm{v})$ Triton $\mathrm{X}-100$ to remove SDS and then incubated for $24 \mathrm{~h}$ at $37^{\circ} \mathrm{C}$ in $100 \mathrm{mM}$ glycine, $10 \mathrm{mM}$ EDTA, pH 8.3. After staining with Coomassie blue R-250, plasminogen-dependent caseinolytic proteins were identified as clear zones of lyses against a blue background. The zymograms were imaged with the Eagle Eye II Still Video System (Stratagene, Santa Clara, CA, USA), and the zones of enzyme activity were quantified as integrated density by densitometric analysis using NIH ImageJ 1.62. Enzyme levels were expressed in arbitrary units set automatically by the software. Human urine urokinase (Calbiochem) was used as reference.

Zymography was also used for MMP9 analysis. In this case, $1 \mathrm{mg} / \mathrm{ml}$ porcine skin gelatin (G2625; Sigma Chemical Co.) was co-polymerized with the gels as enzyme substrate. Zymograms were developed for $48 \mathrm{~h}$ at $37^{\circ} \mathrm{C}$ using $50 \mathrm{mM}$ Tris- $\mathrm{HCl}, \mathrm{pH}$ 7.5, containing $10 \mathrm{mM} \mathrm{CaCl}_{2}, 150 \mathrm{mM} \mathrm{NaCl}$, and $0.5 \%$ Triton $\mathrm{X}-100$. As a positive control for MMP9 activation, MMPs were activated with APMA in blastocyst-conditioned medium obtained on GD 9. A freshly prepared $10 \mathrm{mM}$ solution of APMA in $20 \%$ ethanol was added to conditioned medium in $50 \mathrm{mM}$ Tris- $\mathrm{HCl}, \mathrm{pH} 7.5$, buffer containing $1 \mathrm{mM} \mathrm{CaCl}_{2}$ to give a final APMA concentration of $1 \mathrm{mM}$. The mixture was incubated at $37^{\circ} \mathrm{C}$ for $2 \mathrm{~h}$ before electrophoresis.

\section{Plasmin activity}

Plasmin activity was measured using a specific chromogenic substrate, D-Val-Leu-Lys-4-nitroanilide-acetate (Sigma), which is cleaved by plasmin into a residual peptide and 4-nitroaniline (Ellis et al. 1987). The assay was carried out at $37^{\circ} \mathrm{C}$ in a $0.2 \mathrm{ml}$ reaction mixture containing $50 \mathrm{mM}$ Tris ( $\mathrm{pH} 7.4), 110 \mathrm{mM}$ $\mathrm{NaCl}$, and $0.3 \mathrm{mM}$ of the chromogenic substrate. The absorbance of 4-nitroaniline was monitored spectrophotometrically at $405 \mathrm{~nm}$. To ensure specificity, the results were confirmed by inclusion of the plasmin inhibitor, aprotinin $(2 \mu \mathrm{g} / \mathrm{ml})$, which inhibited nearly all observed plasmin activity.

\section{Statistical analysis}

Each experiment was performed at least three times. The data are presented as the mean \pm s.E.M. ANOVA followed by Tukey's post hoc test was used to compare experimental groups for statistical significance. Percentage was transformed to arcsine before statistical analysis.

\section{Declaration of interest}

The authors declare that there is no conflict of interest that could be perceived as prejudicing the impartiality of the research reported.

\section{Funding}

Supported, in part, by the intramural research program of the Eunice Kennedy Shriver National Institute of Child Health and Human Development, National Institutes of Health, DHHS, NIH grants HD36764, HD045966, and AA12057 to D R Armant and by PAPIIT-DGAPA-UNAM, grant IN 230611 and PAPCA 2006-2007, FES-Iztacala to L A Baiza-Gutman and M G Martinez-Hernandez. Confocal microscopy was supported by center grants ES06639 and CA22453 from the NIH. 


\section{Acknowledgements}

We thank Linda Mayernik for technical assistance with confocal microscopy. M G Martínez-Hernández was a predoctoral fellow of CONACYT, and this study constitutes part of her PhD dissertation for the Posgrado en Ciencias Biológicas, UNAM (México).

\section{References}

Aflalo ED, Sod-Moriah UA, Potashnik G \& Har-Vardi I 2004 Differences in the implantation rates of rat embryos developed in vivo and in vitro: possible role for plasminogen activators. Fertility and Sterility $\mathbf{8 1}$ (Suppl 1) 780-785. (doi:10.1016/j.fertnstert.2003.10.014)

Aflalo ED, Sod-Moriah UA, Potashnik G \& Har-Vardi I 2005 Expression of plasminogen activators in preimplantation rat embryos developed in vivo and in vitro. Reproductive Biology and Endocrinology 37. (doi:10.1186/1477-7827-3-7)

Aflalo ED, Sod-Moriah UA, Potashnik G \& Har-Vardi I 2007 EGF increases expression and activity of PAs in preimplantation rat embryos and their implantation rate. Reproductive Biology and Endocrinology 54. (doi:10.1186/1477-7827-5-4)

Afonso S, Romagnano L \& Babiarz B 1997 The expression and function of cystatin $C$ and cathepsin B and cathepsin $L$ during mouse embryo implantation and placentation. Development 124 3415-3425.

Afonso S, Romagnano L \& Babiarz B 1999 Expression of cathepsin proteinases by mouse trophoblast in vivo and in vitro. Developmental Dynamics 216 374-384. (doi:10.1002/(SICI)1097-0177(199912)216:4/ $5<374::$ AID-DVDY6>3.0.CO;2-N)

Alfano D, Franco P, Vocca I, Gambi N, Pisa V, Mancini A, Caputi M, Carriero MV, laccarino I \& Stoppelli MP 2005 The urokinase plasminogen activator and its receptor: role in cell growth and apoptosis. Thrombosis and Haemostasis 93 205-211. (doi:10.1160/TH04-09-0592)

Armant DR 2005 Blastocysts don't go it alone. Extrinsic signals fine-tune the intrinsic developmental program of trophoblast cells. Developmental Biology 280 260-280. (doi:10.1016/j.ydbio.2005.02.009)

Armant DR 2006 Blastocyst culture. In Placenta and Trophoblast Methods and Protocols, Methods in Molecular Medicine, pp 35-56. Eds MJ Soares \& JS Hunt. Totowa, NJ: Humana Press.

Auman HJ, Nottoli T, Lakiza O, Winger Q, Donaldson S \& Williams T 2002 Transcription factor AP-2gamma is essential in the extra-embryonic lineages for early postimplantation development. Development 129 2733-2747.

Axelrod HR 1985 Altered trophoblast functions in implantation-defective mouse embryos. Developmental Biology 108 185-190. (doi:10.1016/ 0012-1606(85)90021-1)

Behrendtsen O \& Werb Z 1997 Metalloproteinases regulate parietal endoderm differentiating and migrating in cultured mouse embryos. Developmental Dynamics 208 255-265. (doi:10.1002/(SICI)1097-0177 (199702)208:2 <255::AID-AJA12 > 3.0.CO;2-2)

Behrendtsen O, Alexander CM \& Werb Z 1992 Metalloproteinases mediate extracellular matrix degradation by cells from mouse blastocyst outgrowths. Development 114 447-456.

Bonnefoy A \& Legrand C 2000 Proteolysis of subendothelial adhesive glycoproteins (fibronectin, thrombospondin, and von Willebrand factor) by plasmin, leukocyte cathepsin G, and elastase. Thrombosis Research 98 323-332. (doi:10.1016/S0049-3848(99)00242-X)

Brenner CA, Adler RR, Rappolee DA, Pedersen RA \& Werb Z 1989 Genes for extracellular-matrix-degrading metalloproteinases and their inhibitor, TIMP, are expressed during early mammalian development. Genes and Development 3 848-859. (doi:10.1101/gad.3.6.848)

Bugge TH, Flick MJ, Daugherty CC \& Degen JL 1995 Plasminogen deficiency causes severe thrombosis but is compatible with development and reproduction. Genes and Development 9 794-807. (doi:10.1101/ gad.9.7.794)

Caceres M, Tobar N, Guerrero J, Smith PC \& Martinez J 2008 c-jun$\mathrm{NH} 2 \mathrm{JNK}$ mediates invasive potential and EGFR activation by regulating the expression of HB-EGF in a urokinase-stimulated pathway. Journal of Cellular Biochemistry 103 986-993. (doi:10.1002/jcb.21469)
Carroll PM, Richards WG, Darrow AL, Wells JM \& Strickland S 1993 Preimplantation mouse embryos express a cell surface receptor for tissue-plasminogen activator. Development 119 191-198.

Cassady AI, Stacey KJ, Nimmo KA, Murphy KM, von der Ahe D, Pearson D, Botteri FM, Nagamine Y \& Hume DA 1991 Constitutive expression of the urokinase plasminogen activator gene in murine RAW264 macrophages involves distal and $5^{\prime}$ non-coding sequences that are conserved between mouse and pig. Nucleic Acids Research 19 6839-6847. (doi:10.1093/nar/19.24.6839)

Castellino FJ \& Ploplis VA 2005 Structure and function of the plasminogen/plasmin system. Thrombosis and Haemostasis 93 647-654. (doi:10.1160/TH04-12-0842)

Chen L, Nakai M, Belton RJ Jr \& Nowak RA 2007 Expression of extracellular matrix metalloproteinase inducer and matrix metalloproteinases during mouse embryonic development. Reproduction 133 405-414. (doi:10. 1530/rep.1.01020)

Cohen M, Meisser A \& Bischof P 2006 Metalloproteinases and human placental invasiveness. Placenta 27 783-793. (doi:10.1016/j.placenta. 2005.08.006)

Das SK, Wang XN, Paria BC, Damm D, Abraham JA, Klagsbrun M, Andrews GK \& Dey SK 1994 Heparin-binding EGF-like growth factor gene is induced in the mouse uterus temporally by the blastocyst solely at the site of its apposition: a possible ligand for interaction with blastocyst EGF-receptor in implantation. Development 120 1071-1083.

Das SK, Yano S, Wang J, Edwards DR, Nagase H \& Dey SK 1997 Expression of matrix metalloproteinases and tissue inhibitors of metalloproteinases in the mouse uterus during the peri-implantation period. Developmental Genetics 21 44-54. (doi:10.1002/(SICl)1520-6408(1997)21:1<44::AI D-DVG5 > 3.0.CO;2-8)

Dyer KD, Linz-Mcgillem LA, Alliegro MA \& Alliegro MC 2002 Receptorbound UPA is reversibly protected from inhibition by low molecular weight inhibitors. Cell Biology International 26 327-335. (doi:10.1006/ cbir.2001.0859)

Ehnman M, Li H, Fredriksson L, Pietras K \& Eriksson U 2009 The uPA/uPAR system regulates the bioavailability of PDGF-DD: implications for tumour growth. Oncogene 28 534-544. (doi:10.1038/onc.2008.410)

Ellis V, Scully MF \& Kakkar VV 1987 Plasminogen activation by single-chain urokinase in functional isolation. A kinetic study. Journal of Biological Chemistry 262 14998-15003.

Ellis V, Behrendt N \& Dano K 1991 Plasminogen activation by receptorbound urokinase. A kinetic study with both cell-associated and isolated receptor. Journal of Biological Chemistry 266 12752-12758.

Farina AR, Tiberio A, Tacconelli A, Cappabianca L, Gulino A \& Mackay AR 1996 Identification of plasminogen in Matrigel and its activation by reconstitution of this basement membrane extract. BioTechniques 21 904-909.

Fujiwara H 2007 Membrane-bound peptidases regulate human extravillous trophoblast invasion. Placenta 28 (Suppl A) S70-S75. (doi:10.1016/ j.placenta.2007.01.005)

Godar S, Horejsi V, Weidle UH, Binder BR, Hansmann C \& Stockinger H 1999 M6P/IGFII-receptor complexes urokinase receptor and plasminogen for activation of transforming growth factor- $\beta 1$. European Journal of Immunology 29 1004-1013. (doi:10.1002/(SICl)1521-4141(199903)29: $03<1004::$ AID-IMMU1004>3.0.CO;2-Q)

Goldberg GI, Strongin A, Collier IE, Genrich LT \& Marmer BL 1992 Interaction of $92-\mathrm{kDa}$ type IV collagenase with the tissue inhibitor of metalloproteinases prevents dimerization, complex formation with interstitial collagenase, and activation of the proenzyme with stromelysin. Journal of Biological Chemistry $2674583-4591$.

Goldfinger LE, Stack MS \& Jones JC 1998 Processing of laminin-5 and its functional consequences: role of plasmin and tissue-type plasminogen activator. Journal of Cell Biology 141 255-265. (doi:10. 1083/jcb.141.1.255)

Gong Y, Hart E, Shchurin A \& Hoover-Plow J 2008 Inflammatory macrophage migration requires MMP-9 activation by plasminogen in mice. Journal of Clinical Investigation 118 3012-3024. (doi:10.1172/ $\mathrm{JCl} 32750)$

Guerrero J, Santibanez JF, Gonzalez A \& Martinez J 2004 EGF receptor transactivation by urokinase receptor stimulus through a mechanism involving Src and matrix metalloproteinases. Experimental Cell Research 292 201-208. (doi:10.1016/j.yexcr.2003.08.011) 
Hantai D \& Festoff BW 1987 Degradation of muscle basement membrane zone by locally generated plasmin. Experimental Neurology 95 44-55. (doi:10.1016/0014-4886(87)90005-7)

Harvey MB, Leco KJ, Arcellana-Panlilio MY, Zhang X, Edwards DR \& Schultz GA 1995 Proteinase expression in early mouse embryos is regulated by leukaemia inhibitory factor and epidermal growth factor. Development 121 1005-1014.

van Hinsbergh VW, Engelse MA \& Quax PH 2006 Pericellular proteases in angiogenesis and vasculogenesis. Arteriosclerosis, Thrombosis, and Vascular Biology 26 716-728. (doi:10.1161/01.ATV.0000209518. 58252.17)

Hurtado M, Lozano JJ, Castellanos E, Lopez-Fernandez LA, Harshman K, Martinez AC, Ortiz AR, Thomson TM \& Paciucci R 2007 Activation of the epidermal growth factor signalling pathway by tissue plasminogen activator in pancreas cancer cells. Gut 56 1266-1274. (doi:10.1136/gut. 2006.097188)

Jessmon P, Leach RE \& Armant DR 2009 Diverse functions of HBEGF during pregnancy. Molecular Reproduction and Development $\mathbf{7 6}$ 1116-1127. (doi:10.1002/mrd.21066)

Knudsen BS, Silverstein RL, Leung LL, Harpel PC \& Nachman RL 1986 Binding of plasminogen to extracellular matrix. Journal of Biological Chemistry 261 10765-10771.

Korner G, Bjornsson TD \& Vlodavsky I 1993 Extracellular matrix produced by cultured corneal and aortic endothelial cells contains active tissuetype and urokinase-type plasminogen activators. Journal of Cellular Physiology 154 456-465. (doi:10.1002/jcp.1041540303)

Krystosek A \& Seeds NW 1986 Normal and malignant cells, including neurons, deposit plasminogen activator on the growth substrata. Experimental Cell Research 166 31-46. (doi:10.1016/0014-4827(86) 90506-9)

Kuckenberg P, Buhl S, Woynecki T, van Furden B, Tolkunova E, Seiffe F, Moser M, Tomilin A, Winterhager E \& Schorle H 2010 The transcription factor TCFAP2C/AP-2gamma cooperates with CDX2 to maintain trophectoderm formation. Molecular and Cellular Biology $\mathbf{3 0}$ 3310-3320. (doi:10.1128/MCB.01215-09)

Lee S, Jilani SM, Nikolova GV, Carpizo D \& Iruela-Arispe ML 2005 Processing of VEGF-A by matrix metalloproteinases regulates bioavailability and vascular patterning in tumors. Journal of Cell Biology 169 681-691. (doi:10.1083/jcb.200409115)

Lefebvre O, Regnier C, Chenard MP, Wendling C, Chambon P, Basset P \& Rio MC 1995 Developmental expression of mouse stromelysin-3 mRNA. Development 121 947-955.

Legrand C, Polette M, Tournier JM, de Bentzmann S, Huet E, Monteau M \& Birembaut P 2001 uPA/plasmin system-mediated MMP-9 activation is implicated in bronchial epithelial cell migration. Experimental Cell Research 264 326-336. (doi:10.1006/excr.2000.5125)

Leksa V, Godar S, Schiller HB, Fuertbauer E, Muhammad A, Slezakova K, Horejsi V, Steinlein P, Weidle UH, Binder BR et al. 2005 TGF- $\beta$-induced apoptosis in endothelial cells mediated by M6P/IGFII-R and miniplasminogen. Journal of Cell Science 118 4577-4586. (doi:10.1242/jcs. 02587)

Lijnen HR 2002 Matrix metalloproteinases and cellular fibrinolytic activity. Biochemistry 67 92-98. (doi:10.1023/A:1013908332232)

Lijnen HR, Silence J, Van Hoef B \& Collen D 1998 Stromelysin-1 (MMP-3)independent gelatinase expression and activation in mice. Blood 91 2045-2053.

Lim HJ \& Dey SK 2009 HB-EGF: a unique mediator of embryo-uterine interactions during implantation. Experimental Cell Research $\mathbf{3 1 5}$ 619-626. (doi:10.1016/j.yexcr.2008.07.025)

Liotta LA, Goldfarb RH, Brundage R, Siegal GP, Terranova V \& Garbisa S 1981 Effect of plasminogen activator (urokinase), plasmin, and thrombin on glycoprotein and collagenous components of basement membrane. Cancer Research 41 4629-4636.

Liu Z \& Armant DR 2004 Lysophosphatidic acid regulates murine blastocyst development by transactivation of receptors for heparin-binding EGF-like growth factor. Experimental Cell Research 296 317-326. (doi:10.1016/ j.yexcr.2004.02.006)

Lucchesi PA, Sabri A, Belmadani S \& Matrougui K 2004 Involvement of metalloproteinases $2 / 9$ in epidermal growth factor receptor transactivation in pressure-induced myogenic tone in mouse mesenteric resistance arteries. Circulation 110 3587-3593. (doi:10.1161/01.CIR.0000148780. 36121.47)
Mackay AR, Gomez DE, Cottam DW, Rees RC, Nason AM \& Thorgeirsson UP 1993 Identification of the 72-kDa (MMP-2) and 92-kDa (MMP-9) gelatinase/type IV collagenase in preparations of laminin and Matrigel. BioTechniques 15 1048-1051.

Mars WM, Jo M \& Gonias SL 2005 Activation of hepatocyte growth factor by urokinase-type plasminogen activator is ionic strength-dependent. Biochemical Journal 390 311-315. (doi:10.1042/BJ20042028)

Marshall BC, Sageser DS, Rao NV, Emi M \& Hoidal JR 1990 Alveolar epithelial cell plasminogen activator. Characterization and regulation. Journal of Biological Chemistry 265 8198-8204.

Matsuoka H, Sisson TH, Nishiuma T \& Simon RH 2006 Plasminogenmediated activation and release of hepatocyte growth factor from extracellular matrix. American Journal of Respiratory Cell and Molecular Biology 35 705-713. (doi:10.1165/rcmb.2006-0006OC)

Mazzieri R, Masiero L, Zanetta L, Monea S, Onisto M, Garbisa S \& Mignatti P 1997 Control of type IV collagenase activity by components of the urokinase-plasmin system: a regulatory mechanism with cell-bound reactants. EMBO Journal 16 2319-2332. (doi:10.1093/emboj/16.9.2319)

McGuire PG \& Seeds NW 1989 The interaction of plasminogen activator with a reconstituted basement membrane matrix and extracellular macromolecules produced by cultured epithelial cells. Journal of Cellular Biochemistry 40 215-227. (doi:10.1002/jcb.240400210)

Moser TL, Enghild JJ, Pizzo SV \& Stack MS 1993 The extracellular matrix proteins laminin and fibronectin contain binding domains for human plasminogen and tissue plasminogen activator. Journal of Biological Chemistry 268 18917-18923. (doi:10.1002/jcb.240400210)

Naldini L, Vigna E, Bardelli A, Follenzi A, Galimi F \& Comoglio PM 1995 Biological activation of pro-HGF (hepatocyte growth factor) by urokinase is controlled by a stoichiometric reaction. Journal of Biological Chemistry 270 603-611. (doi:10.1074/jbc.270.2.603)

Noel A, Maillard C, Rocks N, Jost M, Chabottaux V, Sounni NE, Maquoi E, Cataldo D \& Foidart JM 2004 Membrane associated proteases and their inhibitors in tumour angiogenesis. Journal of Clinical Pathology $\mathbf{5 7}$ 577-584. (doi:10.1136/jcp.2003.014472)

Ogawa K, Funaba M, Mathews LS \& Mizutani T 2000 Activin A stimulates type IV collagenase (matrix metalloproteinase-2) production in mouse peritoneal macrophages. Journal of Immunology 165 2997-3003.

Olson MW, Bernardo MM, Pietila M, Gervasi DC, Toth M, Kotra LP, Massova I, Mobashery S \& Fridman R 2000 Characterization of the monomeric and dimeric forms of latent and active matrix metalloproteinase-9. Differential rates for activation by stromelysin 1 . Journal of Biological Chemistry 275 2661-2668. (doi:10.1074/jbc.275.4.2661)

Oozono S, Yamauchi N, Nishimura K, Matsumoto K, Watanabe R, Kubota K, Aramaki S, Sato F, Wood C, Soh T et al. 2008 Expression of rat uterine serine proteinases homologous to mouse implantation serine proteinase 2. Journal of Experimental Zoology 310B 642-649. (doi:10. 1002/jez.b.21237)

Peters TJ, Albieri A, Bevilacqua E, Chapman BM, Crane LH, Hamlin GP, Seiki M \& Soares MJ 1999 Differentiation-dependent expression of gelatinase B/matrix metalloproteinase- 9 in trophoblast cells. Cell and Tissue Research 295 287-296. (doi:10.1007/s004410051235)

Quax PH, Grimbergen JM, Lansink M, Bakker AH, Blatter MC, Belin D, van Hinsbergh VW \& Verheijen JH 1998 Binding of human urokinase-type plasminogen activator to its receptor: residues involved in species specificity and binding. Arteriosclerosis, Thrombosis, and Vascular Biology 18 693-701.

Reponen P, Leivo I, Sahlberg C, Apte SS, Olsen BR, Thesleff I \& Tryggvason K 1995 92-kDa type IV collagenase and TIMP-3, but not 72-kDa type IV collagenase or TIMP-1 or TIMP-2, are highly expressed during mouse embryo implantation. Developmental Dynamics 202 388-396. (doi:10.1002/aja.1002020408)

Rijken DC \& Lijnen HR 2009 New insights into the molecular mechanisms of the fibrinolytic system. Journal of Thrombosis and Haemostasis 7 4-13. (doi:10.1111/j.1538-7836.2008.03220.x)

Rockwell LC, Pillai S, Olson CE \& Koos RD 2002 Inhibition of vascular endothelial growth factor/vascular permeability factor action blocks estrogen-induced uterine edema and implantation in rodents. Biology of Reproduction 67 1804-1810. (doi:10.1095/biolreprod.102.006700)

Roztocil E, Nicholl SM, Galaria II \& Davies MG 2005 Plasmin-induced smooth muscle cell proliferation requires epidermal growth factor activation through an extracellular pathway. Surgery 138 180-186. (doi:10.1016/j.surg.2005.06.014) 
Salonen EM, Saksela O, Vartio T, Vaheri A, Nielsen LS \& Zeuthen J 1985 Plasminogen and tissue-type plasminogen activator bind to immobilized fibronectin. Journal of Biological Chemistry 260 12302-12307.

Sappino AP, Huarte J, Belin D \& Vassalli JD 1989 Plasminogen activators in tissue remodeling and invasion: mRNA localization in mouse ovaries and implanting embryos. Journal of Cell Biology 109 2471-2479. (doi:10.1083/jcb.109.5.2471)

Sellens MH \& Sherman MI 1980 Effects of culture conditions on the developmental programme of mouse blastocysts. Journal of Embryology and Experimental Morphology 56 1-22.

Sharma N, Liu S, Tang L, Irwin J, Meng G \& Rancourt DE 2006 Implantation serine proteinases heterodimerize and are critical in hatching and implantation. BMC Developmental Biology 6 61. (doi:10.1186/1471213X-6-61)

Solberg H, Rinkenberger J, Dano K, Werb Z \& Lund LR 2003 A functional overlap of plasminogen and MMPs regulates vascularization during placental development. Development 130 4439-4450. (doi:10.1242/ dev.00642)

Stack S, Gonzalez-Gronow M \& Pizzo SV 1990 Regulation of plasminogen activation by components of the extracellular matrix. Biochemistry 29 4966-4970. (doi:10.1021/bi00472a029)

Stack MS, Rinehart AR \& Pizzo SV 1994 Comparison of plasminogen binding and activation on extracellular matrices produced by vascular smooth muscle and endothelial cells. European Journal of Biochemistry 226 937-943. (doi:10.1111/j.1432-1033.1994.00937.x)

Stahl A \& Mueller BM 1995 The urokinase-type plasminogen activator receptor, a GPI-linked protein, is localized in caveolae. Journal of Cell Biology 129 335-344. (doi:10.1083/jcb.129.2.335)

Strickland S, Reich E \& Sherman MI 1976 Plasminogen activator in early embryogenesis: enzyme production by trophoblast and parietal endoderm. Cell 9 231-240. (doi:10.1016/0092-8674(76)90114-8)

Sun ZG, Shi HJ, Gu Z, Wang I \& Shen QX 2007 A single intrauterine injection of the serine protease inhibitor 4-(2-aminoethyl)benzenesulfonyl fluoride hydrochloride reversibly inhibits embryo implantation in mice. Contraception 76 250-255. (doi:10.1016/j.contraception.2007.05.084)

Tanaka H, Hojo K, Yoshida H, Yoshioka T \& Sugita K 1993 Molecular cloning and expression of the mouse 105-kDa gelatinase cDNA. Biochemical and Biophysical Research Communications 190 732-740. (doi:10.1006/bbrc.1993.1110)

Tanaka SS, Togooka Y, Sato H, Seiki M, Tojo H \& Tachi C 1998 Expression and localization of membrane type matrix metalloproteinase-1 (MT1-MMP) in trophoblast cells of cultured mouse blastocysts and ectoplacental cones. Placenta 19 41-48. (doi:10.1016/S0143-4004(98)90097-2)
Tang L \& Rancourt DE 2005 Murine implantation serine proteinases 1 and 2: structure, function and evolution. Gene 364 30-36. (doi:10.1016/ j.gene.2005.07.041)

Teesalu T, Blasi F \& Talarico D 1996 Embryo implantation in mouse: fetomaternal coordination in the pattern of expression of UPA, UPAR, PAI-1 and $\alpha 2$ MR/LRP genes. Mechanisms of Development 56 103-116. (doi:10.1016/0925-4773(96)00515-1)

Uemura A, Nakamura M, Kachi S, Nishizawa Y, Asami T, Miyake Y \& Terasaki H 2005 Effect of plasmin on laminin and fibronectin during plasmin-assisted vitrectomy. Archives of Ophthalmology 123 209-213. (doi:10.1001/archopht.123.2.209)

Vassalli JD \& Belin D 1987 Amiloride selectively inhibits the urokinase-type plasminogen activator. FEBS Letters 214 187-191. (doi:10.1016/00145793(87)80039-X)

Whiteside EJ, Jackson MM, Herington AC, Edwards DR \& Harvey MB 2001 Matrix metalloproteinase- 9 and tissue inhibitor of metalloproteinase-3 are key regulators of extracellular matrix degradation by mouse embryos. Biology of Reproduction 64 1331-1337. (doi:10.1095/biolreprod64.5. 1331)

Yamamoto H, Flannery ML, Kupriyanov S, Pearce J, McKercher SR, Henkel GW, Maki RA, Werb Z \& Oshima RG 1998 Defective trophoblast function in mice with a targeted mutation of Ets2. Genes and Development 12 1315-1326. (doi:10.1101/gad.12.9.1315)

Yehualaeshet T, O'Connor R, Green-Johnson J, Mai S, Silverstein R, Murphy-Ullrich JE \& Khalil N 1999 Activation of rat alveolar macrophage-derived latent transforming growth factor $\beta-1$ by plasmin requires interaction with thrombospondin- 1 and its cell surface receptor, CD36. American Journal of Pathology 155 841-851.

Zhang X, Shu MA, Harvey MB \& Schultz GA 1996 Regulation of urokinase plasminogen activator production in implanting mouse embryo: effect of embryo interaction with extracellular matrix. Biology of Reproduction 54 1052-1058. (doi:10.1095/biolreprod54.5.1052)

Received 3 August 2010

First decision 26 August 2010

Revised manuscript received 30 October 2010

Accepted 12 November 2010 